Jurnal Kesehatan Masyarakat

\title{
ANALISIS RISIKO PAJANAN PESTISIDA TERHADAP KESEHATAN PETANI
}

\author{
Maria G. Catur Yuantari1 ${ }^{1,3 凶}$, Budi Widianarko ${ }^{1,2}$, Henna Rya Sunoko ${ }^{1}$ \\ ${ }^{1}$ Program Doktor Ilmu Lingkungan Universitas Diponegoro \\ ${ }^{2}$ Program Pascasarjana Lingkungan dan Perkotaan Universitas Soegijapranata \\ ${ }^{3}$ Fakultas Kesehatan Universitas Dian Nuswantoro
}

\section{Info Artikel}

Sejarah Artikel:

Diterima 18 Oktober 2014

Disetujui 8 November 2014

Dipublikasikan Januari 2015

\section{Keywords:}

Farmer;

Pesticide;

Health;

Risk Analysis.

\begin{abstract}
Abstrak
Petani dalam mengolah lahan membutuhkan pestisida untuk memberantas hama dan gulma. Namun di sisi lain pestisida dapat membahayakan kesehatan diri petani, konsumen, organisme non target serta lingkungan. Tujuan penelitian ini untuk mengetahui alur pajanan pestisida yang dapat masuk ke tubuh petani berbasis analisis risiko. Metode penelitian dengan exploratory research dengan desain penelitian cross Sectional. Pengumpulan data dilakukan dengan observasi dan wawancara pada 54 petani. Pajanan pestisida dapat masuk ke dalam tubuh petani melalui kulit, pernapasan dan pencernaan. Petani dapat terpajan pestisida pada waktu membawa, menyimpan, memindahkan konsentrat, mencampur, menyemprot serta membersihkan alat semprot yang telah digunakan. Berdasarkan hasil perhitungan RQ (Risk Quotient) 54 petani mendapatkan nilai lebih dari 1, yang berarti lebih dari batas aman yang diperkenan. $40,7 \%$ petani menggunakan bahan aktif dalam sekali pencampuran lebih dari 10 jenis serta $51,9 \%$ petani melakukan penyemprotan menghabiskan 6-10 tangki dalam sehari. Semakin besar peluang pajanan pestisida dapat meningkatkan tingginya kejadian keracunan kronis pada petani. Analisis risiko dapat memberikan gambaran pajanan pestisida dalam tubuh petani, melalui tahapan identifikasi bahaya, dosis response, penentuan pajanan serta penetapan karakteristik risiko. Petani harus menggunakan pestisida dengan benar dan bijak dengan membaca label kemasan, penyemprotan pada waktu yang tetap dan penggunaan alat pelindung diri untuk menjaga keselamatan di tempat kerja.
\end{abstract}

\section{PESTICIDE EXPOSURE RISK ANALYSIS AGAINST FARMER'S HEALTH}

\begin{abstract}
Farmers cultivate agricultural land require pesticides to eradicate pests and weeds. But on the other hand, pesticide may be risking their own health, consumers, non-target organisms and the environment. The aim of this study to determine the flow of pesticide exposure that can enter the body of farmers based on risk analysis. The method uses an exploratory research with a cross sectional study design. The data collection had been done by observation and interviews with 54 farmers. Farmers exposed to pesticides through dermal, respiratory, and digestion. Farmers may be exposed to pesticides in agricultural land at the time of carrying, storing, transferring the concentrate, mixing, spraying and cleaning spray equipment that has been used. Based on the calculation of the value of RQ (Risk Quotient) 54 farmers obtain the results of more than 1, which means the excess of allowable safe limit. 40.7\% of farmers use the active ingredient in a single mixing more than 10 types of active ingredient and 51.9\% of farmers are spraying spend 6-10 tank in a day. The greater the chance of exposure to pesticides may increase the high incidence of chronic poisoning in farmers. Risk analysis can provide an overview of pesticide exposure in the body of farmers, through the stages of hazard identification, dose response, exposure determination and the determination of risk characteristics. Farmers should use pesticides properly and wisely by reading the instructions on the packaging label, spraying at a fixed time and the use of personal protective equipment to maintain safety at work.
\end{abstract}




\section{Pendahuluan}

Pestisida merupakan suatu zat yang dapat bersifat racun (WHO, 2006; Permentan, 2007), namun di sisi lain pestisida sangat dibutuhkan oleh petani untuk melindungi tanamannya. Perubahan iklim yang terjadi saat ini, menurut Koleva et al., (2009) dapat meningkatkan penggunaan bahan aktif pada pestisida hingga $60 \%$. Petani di Indonesia menjadi sangat tergantung dengan keberadaan pestisida, hal ini diketahui data dari Kementerian Pertanian bahwa terjadi peningkatan jumlah pestisida dari tahun ke tahun dengan jumlah paling banyak yang digunakan adalah insektisida (Direktorat Jendral Prasarana dan Sarana Direktorat Pupuk dan Pestisida Kementerian Pertanian, 2011).

Penggunaan pestisida yang tidak tepat dapat membahayakan kesehatan petani dan konsumen, mikroorganisme non target serta berdampak pada pencemaran lingkungan baik itu tanah dan air. Pencemaran akibat penggunaan pestisida telah dibuktikan dengan beberapa penelitian, antara lain: pencemaran air dan tanah akibat penggunaan pupuk dan pestisida oleh Karyadi (2008) di Kendal; Munawir (2005) di Teluk Jakarta dan Teluk Bangka (2010). Adanya residu pestisida pada wortel akibat penggunaan pestisida organoklorin hal ini telah dibuktikan oleh Sinulingga (2006). Disamping itu, ditemukan juga pestisida pada produk susu di India oleh Subir (2008). Berdasarkan studi litelatur bahwa dampak dari paparan pestisida dapat menyebabkan Multiple myeloma, sarkoma, kanker prostat dan pankreas, kanker rahim, pankreas serta Hodgkin. (Alavanja. 2004; Arcury, 2003; Rich, 2006).

Penggunaan pestisida yang berlebihan akan meningkatkan biaya pengendalian, mempertinggi kematian organisme non target serta dapat menurunkan kualitas lingkungan, hal ini dibuktikan bahwa insektisida golongan organofosfat, karbamat dan piretroid sintesis berpengaruh negatif terhadap musuh alami (Laba, 2010).

Berbagai upaya untuk mengontrol penggunaan pestisida telah dilakukan seperti di China oleh Fen Jin (2010). Monitoring dan analisis risiko pada tanaman omija di Korea oleh Jeong (2011). Pemantauan penggunaan pestisida pada sayuran serta menilai tingkat kesadaran masyarakat dan analisis potensi penyakit akibat paparan pestisida oleh Bempah (2011) dan Palma (2009). Meningkatkan hasil pertanian dengan menerapkan pertanian yang berkelanjutan juga telah dicoba (Rachman Sutanto, 2002). Namun penggunaan pestisida secara tidak tepat masih banyak dilakukan.

Analisis risiko adalah suatu proses ilmiah yang digunakan untuk memperkirakan kemungkinan dampak negatif dari kesehatan karena pajanan bahan kimia berbahaya (enHealth, 2002). Analisis risiko terdiri dari 3 komponen yaitu penilaian risiko (risk assesment), manajemen risiko (risk management) serta komunikasi risiko (risk communication). Penilaian risiko terdapat empat tahapan yang harus dipenuhi untuk mengetahui besarnya risiko yaitu identifikasi bahaya, penentuan dose response, exposure assesment, risk characterization (enHealth, 2002; Oberg, T, 2005; Ramli, 2010).

Berdasarkan beberapa hasil penelitian bahwa penggunaan pestisida dapat berdampak pada kesehatan petani, konsumen dan lingkungan. Pada penelitian ini akan mengkaji alur pajanan pestisida yang masuk ke tubuh petani berbasis analisis risiko yaitu melalui tahap identifikasi bahaya, penentuan dose response, penilaian pajanan hingga penentuan karakteristik risiko dilihat dari nilai RQ (Risk Quotient). Sehingga dapat digunakan untuk menentukan program atau kegiatan pencegahan pajanan pestisida pada tubuh petani.

\section{Metode}

Metode penelitian ini adalah exploratory research dengan pendekatan cross sectional yang dilakukan bulan Mei-Juli 2013 di Desa Curut Kecamatan Penawangan Kabupaten Grobogan. Petani melon merupakan petani yang banyak menggunakan pestisida karena tanaman melon mudah diserang hama dan jamur, namun mempunyai nilai jualnya sangat tinggi. Pengumpulan data dilakukan dengan observasi di lahan pertanian dari mulai pembenihan hingga panen serta wawancara. Pengamatan dilakukan pada 54 petani melon. Pemilihan petani berdasarkan kriteria inklusi yaitu petani yang bertempat tinggal di Desa Curut, sudah mulai menanam melon minimal 1 tahun, usia antara 
25-60 tahun serta bersedia sebagai responden.

\section{Hasil dan Pembahasan}

Petani melon di desa Curut hampir setiap hari terpajan pestisida, hal ini terjadi karena setelah 4 hari tanaman melon ditanam, petani mulai menyemprotkan pestisida. Satu hari ratarata petani menghabiskan waktunya 8 jam yang terbagi dalam dua tahap atau bahkan 3 tahap yaitu pada pagi hari dari jam 07.00- 11.00 WIB dilanjutkan dari pukul 13.00-17.00 WIB bila melon sudah mulai berbuah petani bekerja hingga larut malam karena tanaman diserang oleh tikus sekitar pukul 19.00-22.00 Wib.

Petani melon terpajan pestisida dapat melalui inhalasi hal ini terjadi karena setiap kali menghirup udara di lahan pertanian tanpa disadari petani menghirup pestisida yang telah mereka semprotankan pada tanaman. Disamping itu, pajanan pestisida dapat melalui proses pencernaan, petani membawa bekal makanan ke lahan pertanian tanpa menggunakan penutup makanan. Bekal makan siang yang dibawa dari rumah hanya dimasukkan dalam tas/keranjang. Kebiasaan petani di desa Curut pada waktu siang hari, makan dan minum di lahan pertanian sehingga pestisida dapat masuk melalui proses pencernaan. Pajanan pestisida dapat masuk dalam makanan, hal ini perlu dilakukan pemantauan terus menerus (Zhou et al., 2012). Petani pada saat melakukan pencampuran dan penyemprotan tidak menggunakan alat pelindung diri yang standar, mereka langsung menyentuh pestisida dengan konsentrat tinggi sehingga pajanan pestisida dapat juga melalui dermal.

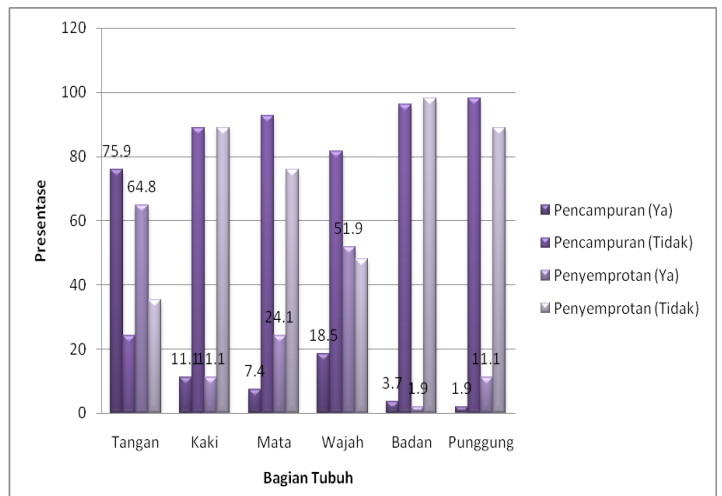

Grafik 1. Bagian Tubuh Yang Dirasa Terkena Pestisida
Sebagian besar petani tidak merasakan tubuhnya terkena pajanan pestisida hanya bagian tangan yang mereka rasakan, bila berdasarkan hasil observasi bagian punggung petani terkena resapan pestisida pada waktu mengggendong tangki penyemprot saat melakukan penyemprotan. Data bagian tubuh yang dirasa oleh Petani terkena pestisida dapat dilihat pada grafik 1 .

Perasaan tidak merasakan pajanan pestisida pada tubuh petani akan berbahaya bila berlangsung terus menerus, karena keracunan kronis banyak yang dialami oleh petani. Jintana (2009) menyatakan pekerja yang terpajan pestisida kadar kolinesterasenya menurun dibandingkan kontrol. Bila pekerja tidak menyadari akan pajanan dalam tubuhnya dapat menyebabkan meningkatnya kejadian keracunan kronis pada pestisida oleh petani. Hal ini didukung oleh penelitian Siwiendayanti A. (2011) pajanan pestisida pada WUS (Wanita usia subur) yang membantu suami atau ayah di lahan pertanian menimbulkan keluhan subjektif seperti mudah lelah, mudah gelisah serta $62,87 \%$ mereka merasakan sakit kepala, walaupun berdasarkan hasil pemeriksaan kadar kolinesterase masih normal. Lorenz (2012) Pekerja wanita di Pertanian sebelum hamil mengetahui bahaya dari penggunaan pestisida sehingga tidak berdampak pada anak yang dikandungnya. Walaupun demikian perlu berhati-hati dalam menggunakan pestisida yang berpotensi menimbulkan dampak negatif.

Menurut Tariq (2007) di Pakistan belum banyak pencatatan terkait dengan penggunaan pestisida serta dampaknya, walaupun secara literatur mereka telah mengetahui dampak negatif dari penggunaan pestisida dampak pada tanah, air, udara dan kesehatan pada manusia. Terdapat peningkatan keracunan pestisida di wilayah pertanian Korea perilaku tidak aman seperti tidak mengikuti instruksi pada kemasan, tidak menggunakan masker dan sarung tangan serta tidak memperhatikan arah angin merupakan faktor risiko mempercepat pajanan pestisida dalam tubuh petani. Dampak dari keracunan pestisida dapat menimbulkan gejala muntah, diare, dyspnea, penglihatan kabur, paresthesia, bicara cadel, dan nyeri dada (Kim J. Hyun, 2013). Risiko Non Hodgkin Lymphoma meningkat dengan meningkatnya penggu- 
naan pestisida. Pajanan pestisida tergantung peran dosis pestisida, lama pajanan dan faktor modifikasi pajanan seperti penggunaan APD (Hohenadel K2011). Pajanan pestisida masuk ke dalam tubuh petani melon dapat melalui proses.

Petani membawa pestisida dari rumah ke lahan pertanian, atau sebaliknya, dapat menyebabkan terjadinya proses pajanan pestisida pada tubuh petani. Proses membawa petani dengan menggendong tangki pada punggungnya, atau menggunakan ember yang diletakkan di sepedanya.

Pencampuran pestisida merupakan proses pengenceran dari konsentrasi yang tinggi ke rendah. Pada waktu pencampuran, pestisida dapat terhirup dan mengenai tubuh petani. Pajanan pestisida semakin banyak mengenai tubuh karena petani jarang menggunakan alat pelindung diri.

Proses penyemprotan merupakan proses pajanan yang paling lama, hal ini sangat tergantung juga dengan luas lahan yang dimiliki. Semakin luas lahan yang dimiliki semakin lama waktu semprotnya sehingga semakin lama proses pajanannya. Pajanan pestisida dalam tubuh petani akan lebih besar karena petani tidak menggunakan masker dan kurang memperhatikan arah angin.

Setelah melakukan penyemprotan alat yang digunakan dicuci, petani dapat terpajan pestisida melalui kulit maupun pernapasan.

Hampir semua petani di Desa Curut menyimpan pestisida yang digunakan di dalam rumah dan diletakkan di ruang tamu. Pestisida yang dibawa ke rumah dapat menyebabkan petani terpajan pestisida melalui pernapasan bila proses penutupan dan penyimpanan kurang tepat.

Pajanan pestisida semakin besar karena selama penggunaan pestisida petani jarang menggunakan alat pelindung yang benar, hal ini juga dilakukan oleh petani di Mesir penelitian oleh Tchounwou et al., (2002) $95 \%$ petani tidak melakukan tindakan keselamatan selama mengaplikasikan penggunaan pestisida. Hal ini juga dilakukan di Brazil bahwa petani sebagian tidak menggunakan alat pelindung diri (Oliveira Pasiani et al., 2012).

Berdasarkan hasil penelitian didapatkan data tentang luas lahan petani di desa Curut
92,6 \% lebih dari $1000 \mathrm{~m}^{2}$, dengan data terbanyak luas lahan antara 3001-4000 $\mathrm{m}^{2}$ sebanyak $37 \%$. Petani menggunakan bahan aktif lebih dari 75\% berjumlah lebih dari 9 jenis bahan aktif. Adapun bahan aktif yang digunakan oleh petani di desa Curut sebagai berikut: Dimenthomorph, Lamda Cyhalothrin, Thiametocsan, Azoxistrobin, Propineb, Carbendazim, Abamectin, Copper Hydroxide, Imidaclopid, Profenofos, Mancozeb, Hecsaconazal, Fenbuconazole, Dimehypo, Tebuconazole, Trifloxystrobin, Phosphoric Acid, Clorantraniliprole, Fibronil, Mefenokem, Fluopicolide, Fenvalerate.

Semakin luas lahan yang dikerjakan maka semakin banyak jumlah tangki yang digunakan untuk melakukan penyemprotan pestisida untuk melindungi tanaman dari serangan hama dan penyakit tanaman. $51,9 \%$ petani di desa Curut melakukan penyemprotan antara 6-10 tangki. Sehingga pajanan pestisida pada petani melon di desa Curut melalui inhalasi, dermal dan digesti semakin besar. Disamping itu penggunaan bahan aktif beberapa jenis dalam sekali pencampuran akan menyebabkan beberapa efek antara lain: independen (tidak saling mempengaruhi), aditif (penambahan sesuai jumlah bahan aktif), sinergi (efek toksik yang ditimbulkan lebih kuat dari jumlah efek yang diberikan), antagonis (akibat penetrasi zat kimia terhadap efek buruk zat kimia lain). Bila tingkat pengetahuan petani terhadap efek toksik pada saat pencampuran pestisida kurang baik dan ternyata bersifat sinergis, hal ini akan membahayakan kesehatan petani dan mikroorganisme lingkungan sekitar pertanian.

Tabel 1. Luas lahan yang dikerjakan oleh Petani di Desa Curut

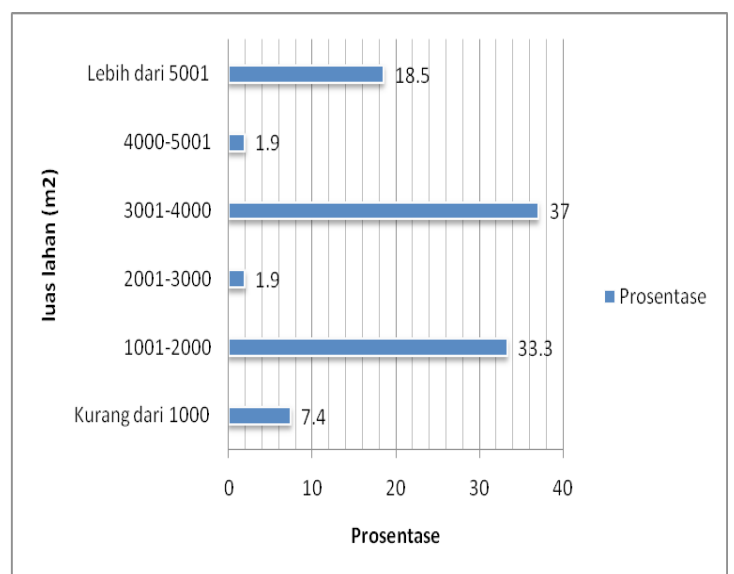


Tabel 2. Jumlah bahan aktif yang digunakan petani di Desa Curut dalam sekali pencampu-

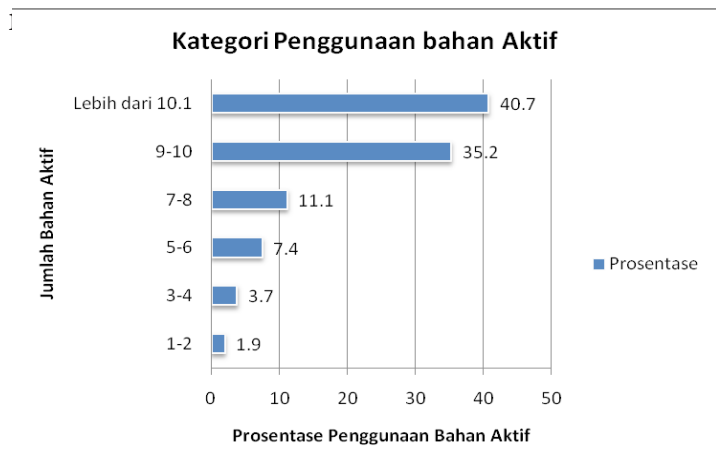

Tabel 3. Kategori Jumlah tangki yang digunakan dalam sehari penyemprotan

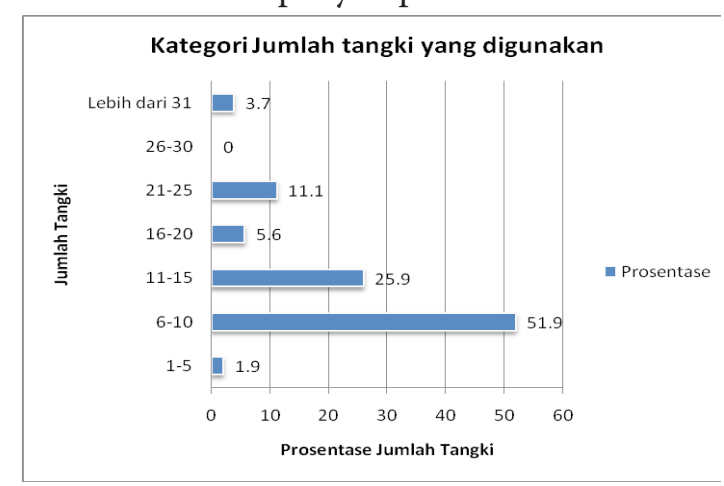

Tabel 4. Kategori nilai RQ Pada Petani di Desa Curut Kecamatan Penawangan

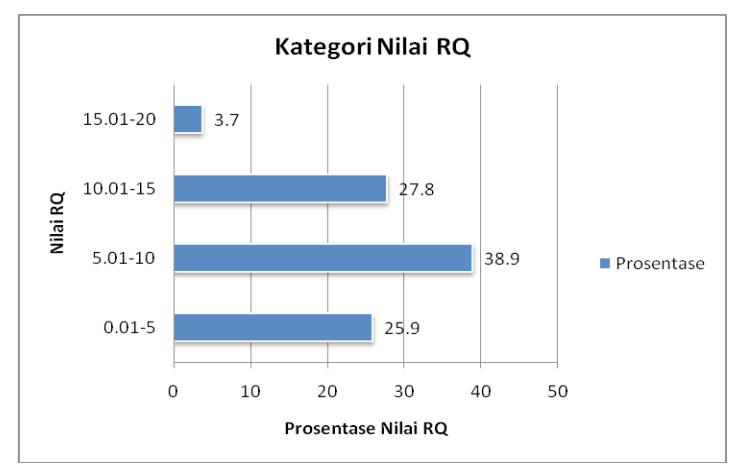

Pada penelitian ini dilakukan juga uji bivariat antara luas lahan dan jumlah bahan aktif dengan nilai RQ. Kategori penentuan luas lahan yang masuk dalam kategori "standar" mempunyai luas kurang dari dan sama dengan $4000 \mathrm{~m}^{2}$ sedangkan kategori "luas" lebih dari $4000 \mathrm{~m}^{2}$. Kategori RQ yang masuk dalam kategori "Aman" kurang dari dan sama dengan 5 sedangkan kategori "tidak aman" lebih dari 5. Berdasarkan hasil penelitian bahwa baik yang mempunyai kategori luas lahan "standar" maupun "luas", nilai RQ yang terbanyak pada batas tidak aman, lebih rincinya dapat dilihat pada tabel 5.

Penentuan kategori aman untuk nilai RQ seharusnya 1 , namun dalam penelitian ini semua responden mempunyai nilai RQ lebih dari 1 hanya $25,9 \%$ nilai RQ petani melon kurang dari dan sama dengan 5. Berdasarkan hasil uji Fisher's Exact Test dengan nilai p value 0.448, bahwa tidak ada hubungan antara luas lahan dengan nilai RQ. Hal ini juga pada jumlah bahan aktif dengan nilai RQ menggunakan uji Rank Spearman didapatkan hasil nilai $\mathrm{p}$ (value) 0,695 sehingga tidak ada hubungan antara bahan aktif dengan nilai RQ. Namun walaupun tidak terdapat hubungan secara signifikan dapat diketahui nilai RQ petani melon di Desa Curut telah melebihi dari batas aman yang diperbolehkan yaitu lebih dari 1, hal ini terjadi karena petani di desa Curut mempunyai kebiasaan mencampur pestisida dengan beberapa jenis pestisida dalam satu tangki.

Perilaku petani di Desa Curut masih belum baik, sehingga petani mudah terpajan pestisida, hal ini juga diperkuat oleh penelitian Sam et al., (2007) perilaku petani dalam menggunakan pestisida masih jauh dari standar aman oleh karena itu perlu pendidikan berkelanjutan dan program pelatihan untuk pekerja petani dengan harap meningkatkan kesadaran dan meminimalkan bahaya kerja.

Penggunaan analisis risiko untuk menilai pajanan pestisida dalam tubuh petani tidaklah mudah, karena sangat tergantung dari tingkat paparan, jenis pestisida yang digunakan, karakteristik lingkungan hal ini dikemukan juga oleh

Tabel 5. Tabulasi silang antara luas lahan dengan nilai RQ

\begin{tabular}{llllllll}
\hline & Kategori & \multicolumn{3}{c}{ Kategori nilai RQ } & \multicolumn{3}{c}{ Total } \\
\cline { 2 - 8 } & Luas Lahan & Aman & $\%$ & Tidak aman & $\%$ & Jumlah & $\%$ \\
\hline Standar & 10 & 23,3 & 33 & 76,7 & 43 & 100 \\
Luas & 4 & 36,4 & 7 & 63.6 & 11 & 100 \\
Total & 14 & 25.9 & 40 & 74.1 & 54 & 100 \\
\hline
\end{tabular}

Sumber : data primer 
Damalas \& Eleftherohorinos (2011), namun tahapan dalam analisis risiko mampu memprediksi pajanan pestisida dalam tubuh petani, konsumen serta lingkungan sehingga dapat untuk menentukan tindakan pencegahan baik terhadap kesehatan manusia serta pencemaran lingkungan.

\section{Penutup}

Perilaku petani dalam menggunakan pestisida masih belum sesuai standar yang diperbolehkan karena telah melakukan pencampuran lebih dari 1 jenis pestisida bahkan ada yang melebihi 10 bahan aktif dalam satu tangki. Petani tidak menyadari bahwa pestisida yang mereka gunakan dapat masuk ke dalam tubuhnya melalui proses dermal, inhalasi, dan digesti, hal ini dapat terjadi pada saat pemindahan, pencampuran, penyemprotan, pencucian serta penyimpanan pestisida.

Berdasarkan hasil perhitungan Risk Quotient (RQ) bahwa nilai petani di desa Curut melebihi dari angka 1 yang berarti melebihi dari batas aman yang diperbolehkan sehingga perlu dilakukan pengurangan pajanan untuk mencegah kecelakaan kerja akibat pajanan pestisida. Disamping itu petani banyak yang tidak menggunakan alat pelindung diri yang sesuai standar keselamatan.

Petani merupakan pekerja sektor informal sehingga sangat tergantung dari peran pemerintah terkait dengan keselamatan kerja dan keamanan pangan sebagai produk hasil pertanian. Untuk itu, pemerintah perlu mengontrol dan mengawasi petani dalam menggunakan pestisida hal ini dapat dilakukan oleh Dinas Pertanian untuk memantau penggunaan pestisida oleh petani. Sebaiknya petani saat menggunakan pestisida memperhatikan petunjuk pada label yang terdapat pada kemasan. Saat melakukan pencampuran, perlu memperhatikan jenis pestisida yang dicampur yaitu bahan aktifnya, jumlah pestisida yang boleh dicampur, serta ketepatan dosis. Disamping itu perlu kepatuhan petani dalam menggunakan alat pelindung diri selama menggunakan pestisida.

Pihak akademisi dapat membantu melalui program pengabdian masyarakat seperti pe- nyuluhan/sosialiasi bahaya pestisida sehingga pengetahuan petani tentang bahaya pestisida akan meningkat dan petani akan lebih bijak dalam menggunakan pestisida.

\section{Ucapan Terimakasih}

Pada penelitian ini peneliti mendapatkan bantuan dukungan dan kerjasama dari Kepala Desa Curut serta kelompok Tani di Desa Curut Kecamatan Penawangan Kabupaten Grobogan Jawa Tengah, untuk itu peneliti mengucapkan terimakasih dan semoga penelitian ini dapat bermanfaat.

\section{Daftar Pustaka}

Alavanja, M.C.R., Hoppin, J.A., Kamel, F., 2004. Health Effects of Chronic Pesticide Exposure: Cancer and Neurotoxicity. Annual Review of Public Health, 25, 155-197.

Arcury, T.A.,Quandt, S.A., 2003. Pesticides at work and at home: exposure of migrant farmworkers. Journal Medical Science, 362(9400), 2021.

Bempah, C.K. 2011. A preliminary assessment of consumer's exposure to organochlorine pesticides in fruits and vegetables and the potential health risk in Accra Metropolis, Ghana. Food Chemistry, 128(4), pp.1058-1065.

Damalas, C.A. \& Eleftherohorinos, I.G., 2011. Pesticide Exposure, Safety Issues, and Risk Assessment Indicators. International Journal of Environmental Research and Public Health, 1402-1419.

Direktorat Jendral Prasarana dan Sarana Direktorat Pupuk dan Pestisida Kementerian Pertanian 2011. Pedoman Pembinaan Penggunaan Pestisida.

Enhealth Council. 2002. Guidelines for assessing human health risks from environmental hazards. Department of Health and Ageing, Population Health Division Publication Distribution Officer MDP 129 GPO box 9848, Canberra 2601

Fen Jin, Jing Wang, Hua Shoa, Maojun Jin. 2010. Pesticide use and residue control in China. J.Pesticide Science Society of Japan, 35 (2): 138-142.

Hohenadel, K, et al. 2011. Exposure to Multiple Pesticides and Risk of Non-Hodgkin Lymphoma in Men from Six Canadian Provinces. International Journal of Environmental Research and Public Health, 2320-2330. 
Jeong, H.R., Lim, S.J., Cho, J.Y., 2011. Monitoring and risk assessment of pesticides in fresh omija (Schizandra chinensis Baillon) fruit and juice. Food and chemical toxicology: an international journal published for the British Industrial Biological Research Association, 1-5.

Jintana, S. Smig K., Krongtong Y., Thanacha S., 2009. Cholinesterase activity, pesticide exposure and health impact in a population exposed to organophosphates. International archives of occupational and environmental health, 82(7): 833-42.

Karyadi, 2008. Dampak penggunaan pupuk dan pestisida yang berlebihan terhadap kandungan residu tanah pertanian bawang merah di Kecamatan Gemuh Kabupaten Kendal. Agromedia, 26 (1): 10-19.

Kim, J. hyun, Kim Jaeyoung, Cha E. Stil, Ko Yousun, Kim D. Hwan, Lee W. Jee, 2013. WorkRelated Risk Factors by Severity for Acute Pesticide Poisoning Among Male Farmers in South Korea. International Journal of Environmental Research and Public Health, 1100-1112.

Koleva, N.G., Schneider, U.A., 2009. The impact of climate change on the external cost of pesticide applications in US agriculture. International Journal of Agricultural Sustainability, 7(3), 203-216.

Laba I Wayan, 2010. Analisis Empiris Penggunaan Insektisida Menuju Pertanian Berkelanjutan. Orasi Profesor Riset di Bogor, Pengembangan Inovasi Pertanian 3: 120-137.

Lorenz, A.N. et al. 2012. Pilot study of pesticide knowledge, attitudes, and practices among pregnant women in northern Thailand. International journal of environmental research and public health, 9(9), 3365-83.

Munawir Khozanah, 2005. Pemantauan Kadar Pestisida Organoklorin di beberapa muara sungai di Perairan Teluk Jakarta. Oseanologi dan Limnologi di Indonesia, 37: 15-25.

Munawir Khozanah, 2010.Pestisida organoklorin di perairan Teluk Klabat Pulau Bangka. Junal oseanologi dan Limnologi di Indonesia, 36 (1): 1-19.

Öberg, T., Bergbäck, B., 2005. Review Articles A Review of Probabilistic Risk Assessment of Contaminated Land. Exposure, 5 (4): 213224.

Oliveira Pasiani J, et al. 2012. Knowledge, attitudes, practices and biomonitoring of farmers and residents exposed to pesticides in Brazil. In- ternational journal of environmental research and public health, 9 (9): 3051-68.

Palma, P., et al, 2009. Risk assessment of representative and priority pesticides, in surface water of the Alqueva reservoir (South of Portugal) using on-line solid phase extraction-liquid chromatography-tandem mass spectrometry. Environment International, 35(3): 545-551.

Permentan, 2007. Peraturan Menteri Pertanian No.07/Permentan/SR.140/2007 tentang Syarat dan Tatacara Pendaftara Pestisida.

Rahman A., Nukman A., Setyadi, Akib R. Carolina, Sofwan, Jarot, 2008. Analisis Risiko kesehatan Lingkungan Pertambangan Kapur di Sukabumi, Cirebon, Tegal, Jepara dan Tulung Agung. Jurnal Ekologi Kesehatan. 7 (1): 665-677.

Ramli Soehatman, 2010. Pedoman Praktis Manajemen Risiko dalam Perspektif K3 OHS Risk Management.Dian Rakyat:Jakarta.

Rich Deborah, 2006. Are pests the Problem or Pesticides. Biology Journal, 28 (1): 6-7.

Sam, K.G., et al. 2008. Effectiveness of educational program to Promote pesticide safety among pesticide handlers of South India. International Archives of Occupational and Environmental Health 81(6): 787-795.

Sinulingga, 2006. Telaah residu organoklor pada wortel Daucus CarotaL Dikawasan sentra Kab.Karo SUMUT. Jurnal Sistem Teknik Industri, 7 (1): 92-97.

Siwiendayanti A., 2011. Keterlibatan Dalam Aktivitas Pertanian dan Keluhan Kesehatan Wanita Usia subur. Jurnal Kesehatan Masyarakat, 7 (1) : 73-82

Subir K. Nag, Mukesh K Raiwar, 2008. Organochlorine Pesticide Recidues in Bovine Milk. Bull Environ Contam Toxicol, 8:(5-9). DOI 10.1007/s00128-007-9276-6.

Tariq, M.Ilyas, Afzal S., Hussain I., Sultana N.,2007. Pesticides exposure in Pakistan: a review. Environment international, 33(8), 1107-22.

Tchounwou P.B., et al. 2002. Health Risk Assessment of Pesticide Usage in Menia El-Kamh Province of Sharkia Governorate in Egypt. Environmental Toxicology, 1082-1094.

WHO. 2006. Sound Management of Pestisicedes And Diagnosis And Treatment Of Pesticide Poisoning

Zhou P. 2012. Dietary exposure to persistent organochlorine pesticides in 2007 Chinese total diet study. Environment International, 42: 152-159. 